\title{
Recycling Poverty through Domestic Service and Adolescent Motherhood
}

\author{
Lorretta F.C. Ntoimo \\ Department of Sociology \\ Faculty of the Social Sciences \\ University of Ibadan, Ibadan
}

DOI: 10.36108/NJSA/1102/90(0130)

Vol. 9 Issue 1, 2011

\begin{abstract}
Engagement in domestic service and adolescent motherhood are two life experiences that impinge on women's life chances and promote inter-generational transmission of poverty. This research examines the socio-economic contexts of domestic service and adolescent childbearing among women from Akwa Ibom State of Nigeria; the link between the two variables and their nexus with poverty. Empirical data for the study were drawn from two life histories and twenty-one In-depth Interviews with women who have experience in domestic service, and those who became mothers as adolescents. The primary determinant of adolescent motherhood and engagement in domestic service is poor socio-economic background. Other significant predisposing factors are negative cultural beliefs that a woman's niche is marriage and motherhood, orphanhood and social network with older domestic servants. Domestic service is found to expose girls to adolescent pregnancy, and adolescent motherhood leads to involvement in domestic work. Domestic service attracts low pay, has a semblance of slavery and the future well being of women engaged in it is uncertain. Further education and opportunities for livelihood skill are stalled for women who become adolescent mothers. This study provides information useful for policies to protect the rights of domestic workers and vulnerable adolescent girls, as well as for poverty alleviation.
\end{abstract}

Keywords: domestic service, adolescent motherhood, poverty, orphanhood, intergenerational transmission

\section{Background to the study}

In spite of global commitments, national programs and private sector initiatives, eradication of poverty has remained a global challenge. The United Nations defines poverty as:

A denial of choices and opportunities, a violation of human dignity. It means lack of basic capacity to participate effectively in society. It means not having enough to feed and clothe a family, not having a school or clinic to go to, not having the land on which to grow one's food or a job to earn one's living, not having access to credit. It means insecurity, powerlessness and exclusion of individuals, households and communities. It means susceptibility to violence, and it often implies living on marginal or fragile environments, without access to clean water or sanitation (UN Statement, June 1998 cited in Gordon, 2005). 

In general, poverty is usually defined in absolute terms of living below a minimum income level of US\$2 or US\$1.25 per day, called poverty line. An estimate by the United Nations Children's Fund' (UNICEF) for 1992-2007 shows that 26 percent of the world population live below poverty line of US\$1.25 per day. In sub-Saharan Africa, the population living below poverty line (US\$1.25 per day) is 53 percent, and 64 percent in Nigeria (UNICEF, 2010; UNDP Multidimensional Poverty Index, 2011). Along gender lines, more women are poor than men, in fact, women constitute two-thirds of the world poor population (Otoo-Oyortey and Pobi, 2003). Clearly, one of the most vulnerable categories of women in poverty lifestyle is female adolescents from poor rural family background (Otoo-Oyortey and Pobi, 2003).

Research shows that one outcome of poverty in sub-Saharan Africa is early entry into formal or informal labour market (Sharif, 2000), such as domestic service. Domestic service is an unregulated sector that is fraught with precarious conditions of service and poor remuneration in many societies (Abu-Habib, 1998; Bruce and Hallman, 2008). Another notable result of poverty in many societies is adolescent motherhood (Bird, 2007; PRB Policy Brief, April, 2011). According to Buvnic et al. (1992), poverty breeds poverty, and one mechanism for transmitting poverty from one generation to another is adolescent pregnancy and childbearing. Relative to boys, "girls bear the major social, economic, cultural and health consequences of early pregnancy" (Dixon-Mueller, 2007: 8). Adolescent childbearing for women, more often than not, hinders opportunities, reflects lack of choice and knowledge, and violation of young people's rights. This paper examines how two interlinking factors of domestic service and adolescent motherhood promote intergenerational transmission of poverty.

Empirical data for the study were based on two life histories, two In-depth Interview with women who became mothers as adolescents, and In-depth Interviews with nineteen women who worked or are currently engaged in domestic service as house girls. The life experiences of the women provide useful insight into how domestic service and adolescent motherhood interlink and independently confine a category of women to inevitable poverty that may be transmitted to their children if no interventions are provided. All the subjects are from Akwa Ibom State in Nigeria, one of the states known for the supply of domestic servants, especially to urban homes (Ering, 2005). There is also relatively high prevalence of adolescent pregnancy and early marriage in that State (Akpan, 2003; NPC and ICF Macro, 2009). Of the three zones in Southern Nigeria, South-South (where Akwa Ibom is located) has the highest percentage of women age 15-19 who have begun childbearing. The figures are 8.1 percent for Southeast, 8.8 percent for Southwest and 11.9 percent for South-South (NPC and ICF Macro, 2009). 


\section{Domestic service}

Although a larger number of women engage in paid employment, the labour market in many societies remains sex segregated (Chant and Pedwell, 2008). Women in Nigeria, as well as other societies still dominate the informal labour sector (FMWA, 2006; Chant and Pedwell, 2008). Domestic service is one of the unregulated informal labour activities in which women predominate, because there is a high demand for girls than boys as house helps. Omokhodion (2009) explains that the higher demand for girls for domestic service in Nigeria is due to a socio-cultural system that socialises girls to perform domestic chores, and child care; household need for house help is usually for such services as child care, domestic chores, shopping and cooking.

One of the ways parents in rural communities in Nigeria respond to the negative effects of large family size and poverty is by sending their children out as domestic servants (Mbakogu, 2004). In some cases, the domestic servants are recruited formally as paid house girls through some agents. In other cases, young children are given out by parents to relatives, non-relatives or neighbours residing in urban areas, to help the children get formal education or livelihood skill in exchange for their domestic service (Isiugo-Abanihe, 1985). However, some of these "guardians", instead of sending these children to school, use them as unpaid servants or street hawkers (Mbakogu, 2004; Okunola and Ikuomola, 2010). Although paid domestic service provides a source of autonomy and empowerment for women, it leads to violation of their human rights and exposes them to precarious situations (Sharif, 2000; Sabban, 2002; Omokhodion, 2009). Domestic service attracts very low pay and often requires no formal training or education. Bruce and Hallman (2008: 229) observed that the working conditions and pay of domestic servants closely resemble slavery. They argued that among younger adolescents living apart from their parents, underage girls in domestic service are particularly vulnerable and neglected. A study of child labour in fostering practices conducted in Surulere, Lagos, Nigeria, found that female foster children (most of whom double as domestic servants) worked more than the males in both domestic and commercial activities (Okunola and Ikuomola, 2010). Domestic servants in Nigeria, as in most countries, have no legal or civil protection. Most female domestic workers face diverse forms of inhuman treatment. They are exposed to rape and sexual assaults by male employers, their sons or male neighbours. Due to little financial resources, they are often forced to exchange sex for money, food, clothing and other needs (Abu-Habib, 1998; Bruce and Hallman, 2008).

\section{Adolescent Pregnancy}

Early childbearing is common in many sub-Saharan African countries, including Nigeria. Population Reference Bureau data show that sub Saharan Africa has the highest percentage of women age 15-19 who give birth in a year (PRB, 2011). Studies on sexuality and reproductive health in Nigeria reveal that sexual activity begins early as in most sub-Saharan African countries 
(Isiugo-Abanihe, 1994; Amazigo et al., 1997; Sharif, 2000; Anochie and Ikpeme, 2001; Caldwell and Caldwell, 2002; NPC and ICF Macro, 2004, 2009). Nigeria's Demographic and Health Survey (2008) shows that 8 percent of males aged 15-19 and more than 20 percent of girls of the same age group have had sex at age 15 . The survey also indicated that 21 percent of women age 15-19 are already mothers, 4.3 percent are pregnant with first child, and 25.2 percent have begun childbearing. Early exposure to sexual relationships for girls leads to the risk of early pregnancy and childbearing, premature drop-out of school, early marriage, early separation or divorce, high exposure to HIV/AIDS, early entrance into the informal labour force, and poverty (Manning, 1993; Isiugo-Abanihe, 1998). These outcomes limit the "quantity and quality of human capital girls develop" (Sharif, 2000: 4), which negatively affects their well being and the life chances of their children (Buvnic et al., 1992; Alexander and Guyer, 1993; Bird, 2007). Other researchers have noted that teenage mothers, especially those with more than one child, are more likely to have bleak educational future, stunted career, and live in poverty (Solomon and Liefield, 1998; Nock, 1998). Although other factors may be implicated in the poverty lifestyle of adolescent mothers, motherhood responsibilities impose further constraints on the educational and career pursuits of adolescent mothers (Lamanna and Reidmann, 2003).

From the literature, predisposition to early sexual initiation, pregnancy and motherhood is associated with factors such as poor socio-economic family background, orphanhood, low knowledge and use of contraceptives among adolescent girls, and patriarchal traditions. In a study of prevalence of sexual activity and outcome among female secondary school girls in Port Harcourt, Nigeria Anochie and Ikpeme (2001) found that 54.1 percent of females who have initiated sexual activity are from large families with low socio-economic background. In Colombia, rural, poorer and less educated girls undergo the earliest sexual transitions (Florez and Soto, 2007). Michael and Tuma (1985) in a study of the influence of family background on entry into marriage and parenthood by young men and women in the United States of America found that low parental income, levels of education and a large number of siblings were unpleasant and unproductive family circumstances that push young people into early marriage and parenthood. Hallman (2008a cited in Bruce and Hallman, 2008) found that living in poor household led to the earlier sexual initiation of girls but not for boys in KwaZulu-Natal. The link between poverty and early marriage is further confirmed in a study of some less developed countries (Otoo-Oyortey and Pobi, 2003; PRB Policy Brief, April, 2011). Little or no personal financial resources and low parental income coerce girls into exchanging sex for money, gifts, food, other basic needs, and sometimes promise of educational sponsorship (Gage and Bledsoe, 1994; Okpani and Okpani, 2000; Hope, 2007; Moore et al., 2007; Bruce and Hallman, 2008). Over 98 percent of adolescent pregnant girls interviewed by Amobi and 
Igwegbe (2004) in Anambra State, South east Nigeria, had sex for material gains such as money, clothing and food.

Amoran et al. (2005) found a significant association between loss of one or more parents and early sexual initiation in Ibadan, Nigeria. NHDS (2008) shows that 14 percent of female orphans and vulnerable children (OVC) aged 15-17 have had sexual intercourse by exact age 15 compared to 5.1 percent for male OVC. The survey also found that rural OVC are less likely than urban OVC to have all three basic material needs met (NPC and ICF Macro, 2009). Referring to the UNFPA, 2002; UNICEF, 2003 and UNAIDS, et. al., 2004; Bruce and Hallman (2008: 228) argued that "regardless of definition used, making the transition to adulthood without one or both parents is believed to be a risk factor for abuse, different forms of unsafe sexual behaviour, and HIV infection among young people - and among girls in particular" In a study of the effects of poverty and orphanhood on young people's behaviour in South Africa it was found that every form of orphanhood influenced young people's sexual behaviour and experiences. Poverty increased girls risks more than boys, while orphanhood exposed both boys and girls to risks of early sexual initiation Hallman (2004, 2005 cited in Bruce and Hallman, 2008).

In addition, studies on sexual activity of adolescents in Nigeria show low awareness and use of contraceptives among sexually active adolescents (Amazigo et al., 1997; Okpani and Okpani, 2000; Otoide et al. 2001; Odimegwu et al., 2002; Adetokunbo et al., 2011). Considering that many cases of first sexual encounter by girls are coerced or unplanned (Moore et al., 2007), non use of contraceptive at first sexual debut increases the likelihood of pregnancy at first sexual encounter, Thus, Anochie and Ikpeme (2001) concluded that most cases of adolescent pregnancy were unwanted. Unwanted pregnancy may result in clandestine abortion and death, early marriage, single motherhood, domestic service, life courses and events that perpetuate poverty.

In his Sexual Webs model, Timiun (2011) identified unsafe sexual behaviour as a product of poverty and patriarchy. A study of adolescent sexuality in two communities in the South-South region of Nigeria where the current study subject come from observed that:

Discrimination and subordination of females are commonly practiced based on gender division of labour. Women and girls are perceived mainly from the point of view of their sexual and reproductive roles; and since they themselves have internalized the beliefs overtime, (that their life's fulfilment depends on whether or not they marry and have children), they seem to devote their lives to the pursuit of that goal (Isiugo-Abanihe and Isiugo-Abanihe, 2007: 69).

Akpan (2003) confirmed that in the Ibibio society, which is the dominant ethnic group in the reference state, marriage is a central element in their culture. A woman has no choice but to be married; unmarried women are 
considered irrelevant in the society and therefore not respected. A woman derives status and prestige from her ability to bear many children (male and female), a belief that encourages early marriage among the Ibibio. Women are seen as part of a man's property, so girls grow up with the notion that husbands provide women's financial and material needs. Young women often would not mind dropping out of school or skills acquisition training to marry, with the hope of economic security in marriage which often turns out to be an illusion. Contemporary economic realities and men's tendency to divert their income to other matters outside their household needs (Bruce, 1995; Fustos, 2010; Akorede, 2010) have continued to erode the assumptions of marriage as an economic haven for women.

Adolescent girls who become pregnant often have the challenge of getting the men to accept responsibility. If the man responsible for the pregnancy is her teacher, neighbour or a married man the chances of acceptance are often slim. Most of the partners of pregnant adolescent girls in Amobi and Igwegbe (2004) were much older men, who also refused to admit responsibility for the pregnancy. The stigma for girls and their parents, and the disadvantages associated with adolescent pregnancy and out of wedlock births pressurise girls and their parents to giving the girls out to undesirable men and so early (Buvnic et al., 1992). If the man is an adolescent, he is likely to deny responsibility because he is still probably in school or in apprenticeship or economically dependent on parents. If he admits responsibility, the burden of caring for the girl will fall on his parents who may also be poor. In many of such cases, if the adolescent boy accepts responsibility, the girl will ultimately quit the marriage for lack of adequate care. Otoo-Oyortey and Pobi, (2003) argued that young brides are more subject to domestic violence than older brides, and in some cases the young brides run away and end up on city streets. This challenge and the cultural pressure to marry, usually leave the girls with the options of unsafe abortion or coerced polygynous union with much older men. Where these options fail or are unavailable, they will become single mothers. After giving birth, as single mothers, their chances of marrying are low, as men who have not married previously usually do not want to take care of a child belonging to another man (Lamanna and Riedmann, 2003; Ringsted, 2004). With half education and half skill or none at all, the most likely job option for such girls is domestic service.

\section{Method}

The study adopted qualitative techniques using two Life Histories and twentyone In-depth Interviews. Of these, there were four cases of adolescent motherhood and nineteen cases of domestic service. Out of the four adolescent motherhood subjects, three also have experience with domestic service. In all, twenty-two subjects had experience with domestic service, eighteen are currently serving as house girls while four have quit domestic service due to 
marriage or engagement in other jobs. The two life history subjects were selected due to their experience with domestic service as well as adolescent motherhood. The subjects were selected through the snowball method. Friends, neighbours and relatives provided contacts to the subjects and after each interview, the subjects gave links to others known to them. The interviews were conducted between May 2010 and September 2011. Pseudonyms Agnes and Berna are used for Life History subject one and two respectively.

\section{Characteristics of the Subjects}

All the respondents migrated from their rural communities in Akwa Ibom State and are currently residing in Lagos except one who lives in Ibadan. The mean age of all the subjects is 24.9 years. The domestic service subjects entered domestic service between age 7 and 17 years, and the four subjects for adolescent motherhood became mothers between age 15 and 17 years. The highest level of education attained by any of the subjects is Ordinary National Diploma (OND) by one subject. Others have attained senior secondary education $(n=10)$, incomplete senior secondary $(n=2)$, incomplete or junior secondary education $(n=5)$ primary education; $(n=4)$ and no education $(n=1)$. Eighteen of the subjects are never married, two are married and three are single mothers. The monthly income of respondents in paid domestic service $(n=20)$ range from $\mathrm{N} 3000$ (US\$18.8) to $\$ 30,000$ (US\$187.5).

\section{Findings}

\section{Socio-economic Contexts of Domestic service and Adolescent Motherhood}

The narratives of the subjects revealed that parental poverty, cultural beliefs that associate womanhood with marriage and motherhood, orphanhood, single motherhood are factors that predisposed women in this study to domestic service and adolescent motherhood.

\section{Parental Poverty}

Parental poverty was a major reason why all the subjects except one $(n=21)$ engaged in domestic service. There was need for them to earn income to sustain themselves and their natal families. In the absence of employment opportunities in the rural areas and insufficient education, domestic service in the urban areas became an attractive option. One of the research subjects, a twenty-four year old house wife said she left her village when she was 15 years old to work as a domestic servant in Lagos. Her father was critically ill and her mother had no sure means of income. She had to work to pay for her father's medical treatment. Unfortunately, her father died shortly after she started work. Narrating what propelled her into domestic service, another respondent said:

That was the only option available for me then. I just finished secondary school, no job, Daddy was not working. I have many siblings, and each of us had to look for a means of livelihood. I also 
needed to save money for my education (32 years old, former Domestic servant).

Another domestic servant stated:

My father is a retired soldier and my mother is a farmer. They are poor. Before I could complete my secondary education, it was very difficult financially. That is why I could not go further. After secondary school I decided to leave for Lagos, to work and train myself (24 years old).

Also, poor parental background predisposed two out of the four adolescent mothers to early sexual initiation and pregnancy. In exchange for food and other basic needs, Agnes and Berna, the Life History subjects, became pregnant at age 15 , shortly after their menarche.

\section{Negative Cultural belief about Women}

Another factor found to predispose female adolescents to early motherhood and domestic service is negative cultural belief that women should be confined to the domestic sphere of marriage and motherhood. One of the research subjects, a 34-year old single mother narrated how such cultural belief led her to seek marriage and motherhood as early as age 16. Her father believed it was unnecessary to educate a woman, because she would eventually become another man's wife. Early, she started making effort to enter into a marital union, a desire that has eluded her till the time of interview. She became pregnant at age 16 for a man who denied responsibility. Still seeking marriage, she had another child for a man who refused to marry her. Another interviewee submitted:

I left the village after primary six, to stay with relatives and work. I have been living in the urban areas for a long time. I can speak English but cannot write well. My father is a palm wine tapper and was poor. Also, I believe ignorance about the value of education prevented my parents from making more effort to send me to school (27 years old, Domestic Servant).

With only primary education, she speaks fluent and good English, but ignorance by her parents as she said, and poverty constrained her to domestic service still, at age 27 .

\section{Orphanhood}

Orphanhood (death of one or both parents) is another identifiable factor associated with exposure to domestic service, and early sexual initiation among 
women in this study. Nine of the subjects are orphans (complete or paternal) and they linked their involvement in domestic service to orphanhood. Paternal orphanhood was a reason why one of the respondents got involved in domestic service and hawking from age 7 . She lost her father, and her mother remarried. Her step-father did not want her, so, her mother sent her to stay with an aunt in Lagos. Another respondent who is a complete orphan avowed:

I lost my father and my mother too. There was nobody to sponsor me to secondary school. I had to work as a housemaid to earn a living and help my siblings. I have three sisters and four brothers (27-years old, Domestic Servant).

Another paternal orphan narrated how she stopped schooling at Junior Secondary School three (JSS3) to start domestic service because there was no money to sustain her education. A 28-year old research subject, who is a case for both adolescent motherhood and domestic service, lost her parents as an infant. Orphanhood exposed her to the risk of child labour, early motherhood, and domestic service.

\section{Other Family Background Factors}

All the research subjects are from monogamous natal families. This implies that polygyny is not implicated in this study as a reason for early motherhood and entrance into domestic service. However, single motherhood created conditions that encouraged early sexual exposure and domestic service. Respondents whose mothers are either widowed or separated stated that their mothers are poor. A domestic servant whose mother is separated recounted:

I could not complete secondary school education due to lack of money to continue; and I needed to help sponsor my younger siblings. My father does not live with my mother. My father resides in Cameroon while my mother is in Akwa Ibom state. I am the eldest child, I had to look for employment to help my mother. I have four younger ones (22years old, Domestic Servant).

Large family size is another obvious reason why females from our study area engage in domestic service. The majority $(n=21)$ have between five and eight siblings; only one whose mother is a divorcee has two siblings and Life History subject two is an only child of a never married single mother.

\section{Social Networking between Older and Younger Domestic Servants}

In addition to the above factors, it is observed that the tendency to get involved in domestic service also stems from a strong social network involving older migrants from Akwa Ibom State who are involved in domestic service, and younger migrants. These older migrants become links for younger migrants to enter into domestic service. They seem to believe in domestic service as a way 
out of poverty as well as accommodation challenge encountered by new migrants in Lagos, since most paid domestic service come with the offer of accommodation. In response to why she is engaged in domestic service, an interviewee replied:

I came to Lagos in 2006 in search of work. I worked in a trading company before joining domestic service because there was no other work and because of the need for accommodation (24-years old, Domestic Servant).

The ease with which the domestic servants linked the researcher with house girls from Akwa Ibom State is suggestive of this network; and every interviewee had more names to give.

\section{Adolescent Motherhood versus Domestic service}

Engagement in domestic service is sometimes an outcome of early motherhood. With little or no education, some adolescent mothers who are not married engage in employment in the informal sector as domestic servants. The twenty-eight year old respondent who is a case of domestic service and early motherhood is currently constrained to domestic work. She became pregnant while in unpaid domestic service and after child birth she is working as a paid house maid. With incomplete secondary education, she could not obtain any better employment, and the responsibility of sole parenting makes it difficult for her to accumulate enough savings to start a small scale business or learn a skill. Conversely, engagement in domestic service especially for adolescent girls predisposes them to early motherhood as in the case of Agnes, whose life history is discussed below.

\section{Life History One - Agnes: From Domestic service to Adolescent Pregnancy}

Agnes is a 35 years old full-time housewife and mother of three female children. At the time of interview, she was pregnant with her fourth child. Agnes is from a monogamous natal home. Her father worked and retired in Cameroon. After his retirement, he returned with his family to settle in his village. Agnes' mother doubles as a Seamstress and farmer. Agnes has seven siblings. Her highest level of education is Junior Secondary School Three (JSS3) which she did not complete. She stopped schooling when she became pregnant at age 15. After twenty years of marriage, Agnes still recounted her life story with strong indignation.

I did not push myself into this. It is my aunty who pushed me into it. She used to send me to the man I married now to collect money: My father was not that poor so he could have taken care of all of us. All my siblings who remained with my father completed their secondary 
education, though none went further. I am the only one who did not complete secondary education. My father was not happy with my cousin who took me to Lagos until he died. When we came back from Cameron, my cousin who lives in Lagos asked my father that she wanted to take me to Lagos, my father refused. She pleaded and promised to send me to school and help me. That is how I followed her to Lagos. But she maltreated me; even to pay my school fees was hard for her. She was not living with her husband. Her husband was working at Uyo and she was in Lagos. Sometimes she will say there is no money for us to eat and she would send me to the man I married now. The man used to visit us and when he comes he will be calling me his wife jokingly. My aunty kept sending me there. It was the man who used to pay my school fees. When I go to his house, he will give me money. You know men, they don't do things for free, they will give you money but one day you must surely sleep with them. That is how I became pregnant four months after my first menses. I was only 15 years old. I stopped school and had to marry him at that age.

Painfully, she further narrated how ignorance of contraceptives led her to unwanted pregnancy, and the pains of early child birth.

I am not happy with what happened to me and I know many girls like that. It was my aunty who pushed me to it. That time I did not know anything about contraceptive. When I missed my period, I told my aunty that I have not seen the menses again, she said it will come, that it ceased because I just started it, not knowing it was pregnancy. Labour to deliver of that first child was very long and tough. I had many injuries. Later I started having problems in my bladder, I could not hold urine again. I went to the doctor who said it can be treated and I have been treated.

She attributed her current state of poverty to the early pregnancy and the consequent pregnancy induced marriage. At 35 years of age, Agnes is a fulltime housewife, she has no education or skill to earn her an independent living. She stated:

I am not doing anything. We are managing with my husband's salary, he is just an ordinary driver and his salary is not much.

Agnes desires to learn garment making and even complete her secondary education, but the family's meagre income is channelled to her children's education and welfare. Agnes did not get involved in domestic service because her father was very poor, but through a relationship with a near relative which was meant to be fosterage. Living with another family where her needs were neglected and unmet exposed her to early sexual initiation. With no knowledge 
of contraceptives her sexual debut led to unwanted pregnancy, marriage and motherhood. Agnes's history exemplifies the vulnerability of under-aged girls who are domestic servants.

\section{Life History Two - Berna: From adolescent motherhood and domestic service}

Berna is a 29-year old single mother, who also became pregnant at age 15 . She is an only child of a never married single mother. Her mother became pregnant for her father, but she was not allowed to marry Berna's father because his family is reputed for wickedness and her mother's people did not want her to be married to such a family. Berna's maternal uncle took care of her. Berna never knew her father until two years ago (2009) when her uncle started maltreating her, then she was told who her real father is. She works as a hair stylist in Lagos. She came to Lagos in 2009 on the initiation of her cousin to start work and through that save money to open her own saloon.

On completing her primary education, there was no money to sponsor her secondary school education. Her mother's relative who was living in Cameroon opted to take her as a domestic servant in exchange for her education.

On getting to Cameroon, I was not sent to school, instead she sent me to hawk. I carried 20 litres of kerosene on my head and hawked around streets on daily basis in addition to house work that I had to do. I carried the kerosene so much that I became bald in the centre of my head. Some persons from my village who live near us in Cameroon took pity on me and reported my plight to my mother in the village. My mother sent for me and I returned to the village. I experienced my first menses at age 15, and also became pregnant at 15 and had a baby at that age.

According to her, she does not blame girls who have no option but to exchange sex for money, food and other basic needs, because that was her case.

I got pregnant for the man who was helping me with money, food and other things I needed. When I became pregnant I had to live with the man until I gave birth to the baby. The man planned to marry me but his friends discouraged him. They told him that I am too young and short. His mother found faults with me each time I had misunderstanding with him. 
All these resulted in their separation, but Berna's child remained with her father. While living with him, the man paid for Berna to learn hair dressing but she did not complete her apprenticeship when they separated.

Shortly after leaving him, I got into domestic service again, for a family in Port Harcourt, who promised to help me continue with my education, but they did not keep their promise. So, I did not serve them for a long time. I returned to the village. With the little hairdressing I learnt, I got employed in a hairdressing saloon around. I negotiated with them to pay me less than the agreed salary so that I can use the opportunity to complete my apprenticeship.

Berna is becoming anxious about her 13-year old daughter who is still living with her father in the village because she does not want her daughter to have similar experiences like her.

I am worried about my daughter. I want to bring her to Lagos, so that I can take care of her, she is already thirteen; but I don't have money to rent a personal apartment. My salary is so small.

Berna resides with her cousin in Lagos, whom she said harasses her sexually. Berna dreads returning to her cousin's house at the end of each working day, and she dares not invite her daughter to Lagos under that circumstance.

Berna's life history might have been better if her single mother had sustainable livelihood. Shortly after her primary education, she got involved in domestic service where she doubled as a street hawker. Exchange of material needs for sex resulted in early motherhood, cohabitation, early separation and single motherhood for Berna. Similarly, the 28-year old single mother cohabited with the father of her son and left him shortly after the birth of their son because of domestic violence she experienced at the hand of the man.

Agnes and Berna are cases of exchanging sex for money involving vulnerable girls, who had no option and no knowledge of contraceptives. They represent several other women from Akwa Ibom State whose life chances are stunted by adolescent childbearing and domestic service.

\section{Domestic Service, Adolescent Motherhood and Poverty Nexus}

Evidence from this study strongly suggests that domestic service and adolescent motherhood predispose women from poor or mother-only families in a patriarchal cultural setting to poverty lifestyle in later years. Although there are some women who overcome the challenges of early motherhood and domestic service and achieved sustainable livelihood, but such women are few. The life chances of several others are stunted by these two interlinking transmitters of poverty. 


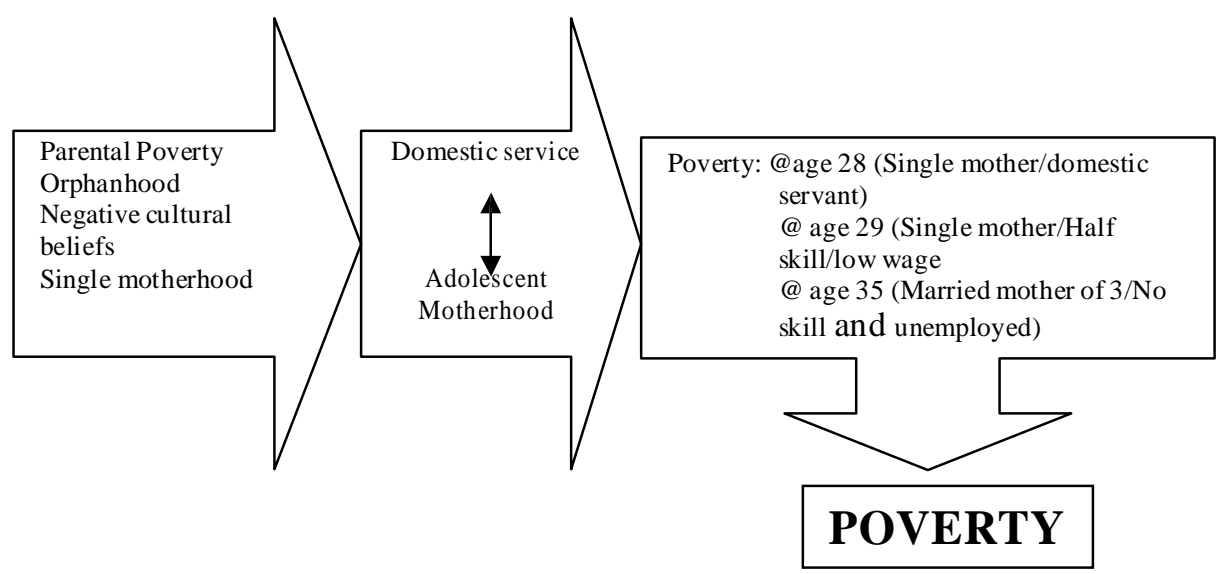

The above schema depicts the outcome of early entrance into domestic service, and adolescent childbearing, on women in their later years. At age 28, 29 and 35, research subjects who became mothers as adolescents are unemployed, without adequate skill, and employed in low-wage jobs. Without sustainable skill and sufficient education these women can only secure lowwage employment in the informal sector or remain unemployed. Consequently, in their late twenties and thirties, they are still enmeshed in poverty. With the immediate responsibility of motherhood, improving their education or learning a livelihood skill surely takes a backseat. Under this circumstance, transmission of poverty to their children becomes a very likely outcome if no intervention takes place. The adolescent-mother respondent who traversed from unpaid domestic service to adolescent motherhood and is currently a paid house girl at age 28 said:

I have no option for now. I work for two families as house help but I don't live with them. I live with my son in one room where we share toilet, kitchen and bathroom with many tenants. What can I do, I take care of my son alone, my income is so small, and his father does not assist me because I did not marry him. I desire to learn a skill or even continue my education but it is difficult financially for me now.

Four respondents in paid domestic service who are in their late twenties and thirties started working as house girls in their adolescence and have worked for over seven years, yet they do not earn more than $\$ 20,000$ (US\$125) per month. A 35-year old interviewee who has been in domestic service for over ten years is paid $\$ 20,000$ per month. Speaking on her working condition and future plan, she said: 
I live with the family I am serving but I buy and cook my own food. They don't provide for me. I work from 6am to 10pm every day. I am off duty only on Sundays. I am not able to save money because the salary is not much. If I see a better work I will leave.

The above woman has no sure plan of what else she could do for a living, but is hoping that one day she will find a better job. The reason is obvious, her income is meagre; she cannot accumulate substantial savings to start a personal business or learn a livelihood skill. She did not complete secondary school, so, she is unlikely to get employed in the formal sector. Even if there is an opportunity to learn a skill free-of-charge, she has only one day in a week for herself. This is the case with many other research subjects in domestic service. Only one woman is granted off duty for three days from Saturday to Monday. One of the domestic servants observed:

You don't have time for yourself. You can't even visit your relatives in Lagos without their permission. All your time is for them, even to worship - attend Christian service they do not allow (22 years old, Domestic Servant).

Low remuneration and the slave-like conditions of domestic service, high rate of unemployment in Nigeria, the socio-economic context of domestic service found in this study, as well as insufficient education make it difficult for these women in domestic service to liberate themselves from the web of poverty. This scenario suggests that domestic servants who are currently adolescents or in their early twenties will remain poor in their later years.

\section{Discussion}

The experiences of women in this study show that the primary socio-economic factors that encourage domestic service and adolescent motherhood are poor family background, negative cultural beliefs, orphanhood and other family background characteristics such as single motherhood and large family size. Domestic service and adolescent motherhood are also found to interlink and promote and reinforce each other.

The study found that poor family background predisposed almost all the respondents in this study to adolescent motherhood or domestic service. This finding confirms previous studies that linked poor parental background and large family size to early sexual exposure and entrance into labour force especially domestic service (Michael and Tuma, 1985; Anochie and Ikpeme, 2001; Amobi and Igwegbe, 2004; Bird, 2007; Bruce and Hallman, 2008). That little or no personal financial resources found to coerce girls into exchanging sex for money is confirmed in three out of the four cases of adolescent motherhood in this study. This supports similar findings in previous research (Gage and Bledsoe, 1994; Okpani and Okpani, 2000; Amobi and Igwegbe, 2004; Hope, 2007; Moore et al., 2007; Bruce and Hallman, 2008). All the 
subjects who are cases of adolescent motherhood, except one became pregnant because they had no knowledge of contraceptives, apart from the fact that they were young, poor and powerless in sex negotiation. Previous studies in different parts of Nigeria associated adolescent motherhood to low knowledge and usage of contraceptives among adolescent girls (Amazigo et al., 1997; Okpani and Okpani, 2000; Otoide, Oronsaye and Okonofua, 2001; Odimegwu, Solanke and Adedokun, 2002; Adetokunbo et al., 2011).

Negative beliefs that the niche of women is marriage and motherhood affected decisions that led to adolescent childbearing as well as early entrance into domestic service among the study subjects. This finding lays credence to previous studies in the study area that associated cultural validation of female subordination and equation of womanhood to marriage and motherhood with early sexual exposure and marriage (Akpan, 2003; Isiugo-Abanihe and IsiugoAbanihe, 2007). Other studies have found that early childbearing and marriage have persisted in many societies due to negative cultural beliefs about women (PRB Policy brief, 2011, Otoo-Oyortey and Pobi, 2003; Akpan, 2003; Jensen and Thornton, 2003).

Complete orphanhood or paternal orphanhood were found to encourage domestic service and early sexual exposure among the research subjects. Previous studies in Nigeria (Amoran et al., 2005; NPC and ICF Macro, 2009), and other countries (Bruce and Hallman, 2008) argued that for girls especially, loss of one or more parents is a risk factor in early sexual exposure, adolescent motherhood, early entrance into labour force, and domestic service.

The study shows how domestic service exposes young girls to unplanned motherhood and marriage; and that adolescent motherhood constrains women to domestic service. Previous studies confirm that domestic service increases the vulnerability of young girls to early sexual initiation (Bruce and Hallman, 2008); and adolescent motherhood stunts the life chances of girls from poor families, rural and patriarchal settings (Sharif, 2000).

The findings show that adolescent motherhood constrained the research subjects to a poverty lifestyle. None of the adolescent mothers in this study has sustainable livelihood at age 28, 29, 34 and 35. Without sustainable livelihood the vicious poverty cycle is often transmitted to the next generation (Buvnic et al., 1992; Alexander and Guyer, 1993; Bird, 2007). Three out of the four adolescent mothers in this study became single mothers. Berna's mother is a single mother, and Berna in turn became a single mother through adolescent pregnancy, Berna has become apprehensive that her thirteen-year old daughter who resides with her father in the village may also become pregnant early and out of wedlock. Mother's marital behaviour has been found to replicate in their daughters (McLanahan, 1988; Kiernan, 1992). Single mother family in most cases has been associated with several negative outcomes for the children such as poverty and the inter-generational transmission of poverty (Buvnic, et al., 1992; Lloyd and Duffy, 1995; McLanahan, 2003; Lamanna and Riedmann, 
2003). Other ills associated with single motherhood are marital instability for the children, early entrance into marriage, cohabitation and unmarried child birth as teens especially for daughters (Goetting, 1983; McLanahan, 1988; Kierman, 1992; Kapinus, 2004; Henslin, 2007), and early entrance into the labour market (Kierman, 1992). All these outcomes culminate in one inevitable principal outcome - poverty.

Two out of the four adolescent motherhood subjects cohabited and separately shortly after the birth of their children. This finding and these women's current economic status confirm that early marriage and motherhood is associated with early separation, and other disadvantages in terms of education, acquisition of livelihood skills, physical security, health risk, poverty and the transmission of poverty to the next generation (PRB, Policy Brief, 2011; Fustos, 2010; Otoo-Oyortey and Pobi, 2003; Jensen and Thornton, 2003; Akpan 2003). The probability of marriage is low for these single mothers. Single motherhood is stigmatised and never married men tend to avoid such women for marriage (Lamanna and Riedmann, 2003; Ringsted, 2004).

The poor conditions of domestic service found in this study supports previous research outcomes on domestic service in Nigeria (Mbakogu, 2004; Okunola and Ikuomola, 2010) and other countries (Abu-Habib, 1998; Sabban, 2002). In fact, Bruce and Hallman (2008) argued that it resembles slavery. Only eight women in this study earn monthly income that is more than the Nigeria's minimum wage of N18,000 (US\$120). Labour laws protecting the rights of employees in the organised public and private sector to the minimum wage and other conditions of service is scarcely applicable to domestic service. Domestic service in its current structure depicts a sure route to transmission of poverty to the next generation.

\section{Conclusion and Recommendations}

This study indicates that the inevitable consequence of adolescent motherhood and domestic service, two interlinking phenomena, in the context of parental poverty, orphanhood, and patriarchal culture, is poverty and the recycling of it, Adolescent motherhood and domestic service limit the ability of poor adolescent girls to develop sustainable livelihood. The life experiences of women in this study reflect the state of millions of other girls living under similar circumstances in Nigeria who are being constrained by poverty, early childbearing, unfair cultural ideologies, domestic service, and orphanhood, to a course of life that recycles poverty to the next generation. Nigeria is surely face-to-face with a segment of women who will not escape poverty if no targeted intervention strategies are put in place to discourage lifestyles and socio-cultural environment that perpetuate poverty.

There, is, therefore need for long term intervention strategies in urban areas and rural communities from where these women migrate to urban centres. Accessible, functional, well publicised and affordable livelihood skills acquisition training centres should be provided to make young women 
economically independent. Special schools should be established where adolescent girls can continue schooling while pregnant, or return to after delivery, if they do not wish to return to their former schools. There should be intensive reorientation campaign to encourage adolescent girls who become pregnant to return to school while pregnant or after delivery.

Bruce and Hallman (2008) argued that research attests to girls' strong interest in acquiring livelihood skills, and the potential impact of even modestly successful interventions on girls' positive sense of their possibilities. Some studies, according to Buvnic et al., (1992), suggest that the perpetuation of disadvantages and poverty from one generation to another can be moderated or reversed if mother's fortune change. Buvnic et al., cited Furstenberg et al. (1987) who found that fortune change in form of having opportunity to continue her studies during or after pregnancy or to attend skills training courses can moderate or reverse the downward cycle. Other empirical findings show that continuing education after pregnancy, and acquisition of livelihood skills are keys to reducing the cycle of poverty (Oyortey and Pobi, 2003; Bird, 2007; Fustos, 2010).

Evidence from the extant and previous studies (Abu-Habib, 1998; Bruce and Hallman, 2008) shows that domestic service is a domain that is driven by poverty, fraught with exploitation, laden with poor working conditions and recycles poverty. There is need for legislations to protect the rights of women engaged in domestic service. As the need for dual income household continues to increase due to global economic recession, the demand for domestic servants will keep rising. It is urgent, therefore, that intervention policies be put in place to protect women in domestic service, and guarantee their right to sustainable income levels.

The negative effects of adolescent motherhood on women call for a more rigorous and wholesome sex education for female adolescents. The aim of such education should not only be to equip young girls with knowledge of contraceptives, it should primarily be to equip them with their reproductive rights and the dangers associated with early motherhood. There is need for community-based campaigns to educate girls and their parents on the value of their girl child and to encourage parents to reduce family size. Large family size is the reason why some of the women in this study who are not orphans entered in to domestic service.

\section{References}

Abu-Habib, L. (1998) The use and Abuse of female domestic workers from Sri Lanka in Lebanon. Gender and Development, 6(1):52-56.

Adetokunbo T.; Akinola, O.; Babatunde, A.; Adeniyi A.; Osinusi 1, D. and Shittu, L. (2011) Contraceptive knowledge and usage amongst female 
secondary school students in Lagos, Southwest Nigeria. Journal of Public Health and Epidemiology 3(1):34-37.

Akpan, E. (2003) Early Marriage in Eastern Nigeria and the Health Consequences of Vesico- Vaginal Fistulae (VVF) among young mothers. Gender and Development, 11(2):70-76.

Alexander, C.S. and Guyer, B. (1993) Adolescent Pregnancy: Occurrence and Consequences. Paediatric Annals, 22:85-88.

Amazigo, U.; Silva, N.; Kaufman, J. and Obikeze, D.S. (1997) Sexual Activity and Contraceptive Knowledge and Use among In-school Adolescents in Nigeria. International Family Planning Perspective, 23(1):28-33.

Amobi, I. and Igwegbe, A. (2004) Unintended Pregnancy among Unmarried adolescents and Young women in Anambra State, South East Nigeria. African Journal of Reproductive Health, 8(3):92-102.

Amoran, O.E.; Onadeko, M.O. and Adeniyi, J.D. (2004-2005) Parental Influence on Adolescent Sexual Initiation Practices in Ibadan, Nigeria. International Quarterly of Community Health Education, 23(1):73-81.

Anochie, I.C. and Ikpeme, E.E. (2001) Prevalence of Sexual activity and Outcome among Female Secondary School Students in Port Harcout, Nigeria. African Journal of Reproductive Health, 5[2]:63-67.

Akorede, Y.O. (2010) Who Picks the Bill? Women and Finance in the Family: A Literary Perspective. International Journal of Gender and Child Education in Africa, 2(2):1-18.

Bird, K. (2007) The Intergenerational transmission of poverty: An overview. Overseas Development Institute, United Kingdom. Chronic Poverty Research Centre (CPRC) Working Paper 99.

Bruce, J. (1995) The Economics of Motherhood. Families in Focus: New Perspectives on Mothers, Fathers, and Children. New York: The Population Council.

Bruce, J. and Hallman, K. (2008) Reaching the girls left behind. Gender and Development, 16(2):227-245.

Buvnic, M.; Valenzuela, J.P.; Molina, T. and Gonzalez, E. (1992) The Fortunes of Adolescent Mothers and their Children: The Transmission of Poverty in Santiago, Chile. Population and Development Review, 18(2):269-297.

Caldwell, J.C. and Caldwell, P. (2002) The Fertility Transition in Sub-Saharan Africa. A paper presented at the Conference Fertility and the Current South Africa Issues of Poverty, HIV/AIDS and Youth. Pretoria, South Africa: Department of Social Development and Human Sciences Research Council.

Chant, S. and Pedwell, C. (2008) Women, gender and the informal economy: An Assessment of ILO research and suggested ways forward. Discussion paper, ILO, Geneva.

Dixon-Mueller, R. (2007) Sexual and Reproductive Transitions of Adolescents in developing Countries. IUSSP Policy \& research Papers no 20. 
Ering, S.O. (2005) Trafficking in persons: Its dynamics and implications for socioeconomic development of rural Nigeria. Calabar Journal of Politics and Administration, 3(1):120-140.

Florez, C.E. and Soto, V.E. (2007) Adolescent fertility in Colombia: What do we know? In R. Dixon-Mueller Sexual and Reproductive Transitions of Adolescents in Developing Countries IUSSP Policy \& research paper no 20.

Fustos, K. (2010) Despite Wide-Ranging Benefits, Girls' Education and Empowerment Overlooked in Developing Countries. www.prb.org/ Articles/2010/girlseducationww.prb.org/Articles/2010/girlseducation.aspx.

Gage, A.J. and Bledsoe, C. (1994) The Effects of Education and Social Stratification on Marriage and the Transition to Parenthood in Freetown, Sierra Leone. Bledsoe, C. and Pison, G. (eds.), Nuptiality in Sub-Saharan Africa: Contemporary Anthropological and Demographic Perspective. Oxford: Carendon Press. pp 148-164.

Goetting, A. (1983) Divorce Outcome Research: Issues and Perspectives. Family in Transition. 4th Edition. Skolnick, A. S. and Skolnick, J. H. (eds.). Canada: Little Brown and company (Canada) Limited. pp 367-38.

Gordon, D. (2005) Indicators of Poverty \& Hunger. Expert Group Meeting on Youth Development Indicators United Nations Headquarters, New York 12th-14th Dec. http://www.un.org/esa/socdev/unyin/documents/ydiDavid Gordon_poverty.pdf.

Haralambos, M. and Holborn, M. (2008) Sociology Themes and Perspectives. 7th Edition. London: HarperCollins Publishers Limited.

Henslin, J.M. (2007) Sociology - A down-to-earth approach. 8th edition. Boston: Pearson.

Hope, R. (2007) Addressing Cross-Generational Sex; A desk Review of Research and Programs. Population Reference Bureau.

Isiugo-Abanihe, U.C. (1985) Child fosterage in West Africa. Population and Development Review, 11(1): 53-74.

Isiugo-Abanihe, U.C. (1994) The Correlates of Premarital Sexuality in Nigeria. African. Journal for the Psychological Study of Social Issues, 1(2): 257276.

Isiugo-Abanihe, U.C. (1998) Stability of Marital Unions and Fertility in Nigeria. Journal of Biosocial Science, 30(1): 33-41.

Isiugo-Abanihe, I.M. and Isiugo-Abanihe, U.C. (2007) Adolescent Sexuality and Reproductive Health in two oil Producing Communities in Imo and Rivers States, Nigeria. African Population Studies, 22(2): 47-76.

Jensen, R. and Thornton, R. (2003) Early female marriage in the developing world. Gender and Development, 11(2):9-19.

Kapinus, C.A. (2004) The Effect of Parents' Attitudes towards Divorce on Offspring's Attitudes: Gender and Parental Divorce as Mediating factors. Journal of Family Issues, 25(1):112-135. 
Kiernan, K.E. (1992) The Impact of family Disruption in Childhood on Transitions made in young Adult life. Population Studies, 46(2): 213-234.

Lamanna, M.A. and Riedmann, A. (2003) Marriages and Families - Making Choices in a diverse society. 8th edition. Belmont, USA: Wadsworth/ Thomson Learning Inc.

Lloyd, C.B. and Duffy, N. (1995) Familial Risk factors for Children. Families in Focus: New Perspectives on Mothers, Fathers, and Children. New York: The Population Council.

Manning, W.D. (1993) Marriage and Cohabitation Following Premarital Conception. Journal of Family and Marriage, 55(3):839-850.

Mbakogu, I.A. (2004) Exploring the Forms of Child abuse in Nigeria: Efforts at Seeking appropriate Preventive Strategies. Journal of Social Sciences, 8(1) 23-27.

McLanahan, S.S. (1988) Family Structure and Dependency: Early Transition to Female Household Leadership. Demography, 25(1): 1-16.

McLanahan, S.S. (2003) Fragile Families and the Marriage Agenda. Rocco C. and Marion S. Siciliano, Forum, Utah.

Michael, R.T. and Tuma, N.B. (1985) Entry into Marriage and Parenthood by young men and women: The influence of family background. Demography, 22(4): 515-544.

Moore, A.M., Awusabo-Asare, K., Madise, N., John-Langba, J., and KumiKyereme, A. (2007) Coerced First Sex among adolescent Girls in subSaharan Africa: Prevalence and Context. African Journal of Reproductive Health, 11(3):62-82.

Federal Ministry of Women Affairs and Social Development (FMWA) (2006) National Gender Policy. Abuja.

National Population Commission (NPC) and ORC Macro (2004) Nigeria Demographic and Health Survey 2003. Abuja: NPC.

National Population Commission (NPC) and ICF Macro (2009) Nigeria Demographic and Health Survey 2008. Abuja: NPC.

Nock, S.L. (1998) The consequences of Premarital Fatherhood. American Sociological Review, 63(2):250-263.

Odimegwu, C.O.; Solanke, L.B. and Adedokun, A. (2002) Parental Characteristics and Adolescent Sexual behaviour in Bida local Government Area of Niger State, Nigeria. African Journal of Reproductive Health 6(1):95-106.

Okpani, A.O.U. and Okpani, J.U. (2000) Sexual Activity and Contraceptive Use among Female Adolescents - A Report from Port Harcourt, Nigeria. African Journal of Reproductive Health, 4(1):40-47.

Okunola, R.A. and Ikuomola, A.D. (2010) Child Labour in Fostering Practices: A Study of Surulere Local Government Area Lagos State, Nigeria. The Social Sciences, 5(6):493-506.

Omokhodion, J.O. (2009) Linking the dominance of House Girls in Nigerian Households to the Girl-child socialization Pattern in Nigeria. Current Research Journal of Social Sciences, 1(2):1-3. 
Otoide, V.O., Oronsaye, F., Okonofua, F.E. (2001) Sexual behaviour and contraceptive use among secondary school adolescents in Benin City, Nigeria. Journal of Obstetrics \& Gynaecology, 21(3):298-302.

Otoo-Oyortey, N. And Pobi, S. (2003) Early Marriage and Poverty: Exploring Links and Policy Issues. Gender and Development, 11(2):42-51.

Population Reference Bureau (PRB) (2011) The World's Women and Girls Data Sheet Washington DC: PRB.

Population Reference Bureau Policy Brief (April 2011) Who speaks for Me? Ending Child Marriage. Washington DC: PRB.

Ringsted, M. (2004) Growing up Pregnant: Events of Kinship in Everyday Life. Africa Sociological Review, 8(1):100-117.

Sabban, R. (2002) United Arab Emirates: Migrant Women in the United Arab Emirates -The Case of Female Domestic Workers. GENPROM Working Paper No.10 (Series on Women and Migration). Geneva: Gender Promotion Programme, International Labour Office.

Sharif, N. (2000) Developing Sustainable Livelihoods: The Case of Poor Female Youth in Sub-Saharan Africa. Journal of Sustainable Development in Africa - jsd-africa.com.

Solomon, R. and Liefield, C.P. (1998) Effectiveness of a Family Support Centre approach to Adolescent Mothers: Repeat Pregnancy and School Drop-out-Rate. Family Relations, 47(2):139-144.

Timiun, G.A. (2011) Sexual Webs for the Explanation of Unsafe Sexual Behavior: Knitting all the Perspectives of Unsafe Sexual Behavior. International Journal of Humanities and Social Science, 1(17):118-125.

UNDP (2011) Human Development Report, Multidimensional Poverty Index Table 5 UNICEF, The State of the World Children/Special Edition. 2010 Economic Indicators. 